\title{
DEVELOPMENT OF RECHARGEABLE MICROBATTERIES FOR AUTONOMOUS MEMS APPLICATIONS
}

\author{
L.G. Salmon, R.A. Barksdale, B. R. Beachem \\ Electrical and Computer Engineering, Brigham Young University \\ Provo, Utah 84602-4101
}

\author{
R. M. LaFollette \\ Bipolar Technologies Incorporated \\ Provo, Utah 84604
}

\author{
J.N. Harb, J. D. Holladay, P.H. Humble \\ Chemical Engineering, Brigham Young University \\ Provo, Utah 84602-4101
}

\begin{abstract}
This paper outlines fabrication and evaluation of a thin-film, rechargeable microbattery that provides sufficient power for many autonomous MEMS applications. Initial prototype microbattery cells achieved current densities greater than $12 \mathrm{~mA} / \mathrm{cm}^{2}$ and were recharged for more than 260 cycles at an operating voltage of $\sim 1.5$ volts. Other prototype microbattery cells produced current densities greater than $18 \mathrm{~mA} / \mathrm{cm}^{2}$ and successfully recharged more than 35 times. The microbattery reported here was fabricated using high-volume, thin-film processes that produce microbattery cells with thicknesses of less than $100 \mu \mathrm{m}$ (excluding the inert substrate)and a form factor consistent with high-volume electronic assembly methods.
\end{abstract}

\section{MEMS REQUIREMENTS FOR MICROBATTERIES}

MEMS devices have the potential to revolutionize the way computational capability connects with the world of our experience. The paradigm of fabrication for MEMS provides the promise of inexpensive, capable sensing/actuation systems that will permeate our lives in the future. MEMS promise to greatly enhance the gathering, evaluation, and communication of information in future applications.

The great strength of MEMS as a technology frequently depends on 1) the ability that MEMS provides to combine great functionality in a single, integrated system solution, 2) the low-cost, high-volume nature of MEMS fabrication, and 3) the overall reduction in size and mass of sensor/actuator systems. Most existing technology emphasizes development of the technology necessary to fabricate MEMS and electronic devices that meet these three goals. The overall goals of many applications will not be met, however, unless an appropriate power source solution is developed as well. For many applications a thin-film microbattery is such a power source solution.

Table 1 compares the characteristics of several power source options with respect to size, weight, energy supply capability, and difficulty of assembling the battery into a low-cost, high-volume system. The characteristics of each of these power sources determines the area of application for which they can be used. As can be seen from the table, the microbattery provides a small, rechargeable, easily integrable power solution that no other power option provides. Of particular interest is the capability of microbatteries to be integrated into complete MEMS systems using automated assembly techniques developed for electronic systems. Use of these assembly techniques sharply decreases the cost and increases the obtainable complexity of integrated MEMS systems.

\begin{tabular}{|c|c|c|c|c|}
\hline $\begin{array}{c}\text { Power } \\
\text { Source }\end{array}$ & Size & Weight & $\begin{array}{c}\text { Energy } \\
\text { Capability }\end{array}$ & $\begin{array}{c}\text { Assembly } \\
\text { Difficulty }\end{array}$ \\
\hline $\begin{array}{c}\text { From the } \\
\text { Wall }\end{array}$ & Very Large & N/A & High & N/A \\
\hline $\begin{array}{c}\text { Battery } \\
\text { Brick }\end{array}$ & Large & Heavy & Moderate & $\begin{array}{c}\text { Very } \\
\text { Difficult }\end{array}$ \\
\hline $\begin{array}{c}\text { Coin } \\
\text { Type } \\
\text { Battery }\end{array}$ & Small & Light & Low & Difficult \\
\hline $\begin{array}{c}\text { Micre- } \\
\text { battery }\end{array}$ & Micro & Very Light & Low & Simple \\
\hline
\end{tabular}

Table 1 - Qualitative comparison of power source characteristics

Table 2 lists several potential high-volume applications for MEMS together with an indication of the power source requirements for the majority of applications in the given application area. As shown in the table, many of the application areas require an integrable microbattery power solution. In general, systems that require mobile, autonomous, extensively integrated sensors require a microbattery solution. A requirement for mobility excludes standard wired power sources. A requirement for autonomy excludes primary battery systems that cannot power integrated systems for extended periods. A requirement for small size, extensive integration, and large numbers of units excludes the use of coin or standard format batteries because of the difficulty of automated mounting such batteries into integrated system formats.

Microbatteries also have performance advantages that can be critical to specific system applications such as: multiple, definable voltage levels, high level of integrability, and better power distribution. 


\begin{tabular}{|c|c|c|c|c|c|}
\hline $\begin{array}{c}\text { Applica- } \\
\text { ton/ } \\
\text { Require- } \\
\text { ment }\end{array}$ & $\begin{array}{c}\text { Remote } \\
\text { Sensing } \\
\text { Arrays }\end{array}$ & $\begin{array}{c}\text { Integrated } \\
\text { Fluidic } \\
\text { Systems }\end{array}$ & $\begin{array}{c}\text { Low- } \\
\text { power } \\
\text { Displays }\end{array}$ & $\begin{array}{l}\text { Embedde } \\
\text { d Sensors }\end{array}$ & $\begin{array}{c}\text { Optical } \\
\text { MEMS }\end{array}$ \\
\hline Size & Micro & Small & $\begin{array}{c}\text { Small/ } \\
\text { Large }\end{array}$ & $\begin{array}{c}\text { Micro/ } \\
\text { Small }\end{array}$ & $\begin{array}{c}\text { Micro/ } \\
\text { Small }\end{array}$ \\
\hline Weight & $\begin{array}{c}\text { Very } \\
\text { Light }\end{array}$ & $\begin{array}{c}\text { Light/ } \\
\text { Heavy }\end{array}$ & $\begin{array}{c}\text { Light/ } \\
\text { Heavy }\end{array}$ & $\begin{array}{c}\text { Light/ } \\
\text { Very } \\
\text { Light }\end{array}$ & $\begin{array}{c}\text { Light/ } \\
\text { Very } \\
\text { Light }\end{array}$ \\
\hline Energy & Low & Moderate & Moderate & Low & $\begin{array}{c}\text { Low/ } \\
\text { Moderate }\end{array}$ \\
\hline $\begin{array}{c}\text { Assembly } \\
\text { Difficulty }\end{array}$ & Simple & Moderate & Moderate & Simple & $\begin{array}{c}\text { Simple/ } \\
\text { Moderate }\end{array}$ \\
\hline $\begin{array}{c}\text { Extemal } \\
\text { Recharge }\end{array}$ & Required & $\begin{array}{c}\text { Not } \\
\text { Always } \\
\text { Required }\end{array}$ & Required & Required & $\begin{array}{c}\text { Not } \\
\text { Always } \\
\text { Required }\end{array}$ \\
\hline $\begin{array}{c}\text { Required } \\
\text { Power } \\
\text { Solution }\end{array}$ & $\mu$ Battery & $\begin{array}{c}\text { Coin/ } \\
\mu \text { Battery }\end{array}$ & $\begin{array}{c}\mu \text { Brick/ } \\
\text { Battery }\end{array}$ & $\mu$ Battery & $\begin{array}{c}\text { Coin/ } \\
\mu \text { Battery }\end{array}$ \\
\hline
\end{tabular}

Table 2 - MEMS applications and associated power source requirements

\section{BACKGROUND}

Thin-film rechargeable batteries (batteries with active layers on the order of $1-10 \mu \mathrm{m}$ ) have been a topic of research since at least the early 1980s. Thin-film microbatteries using a metallic lithium electrode layer have been reported.[1] These batteries have lateral dimensions greater than a centimeter and produced relatively low current densities.

Bates et al. built on this work and reported a thin-film, microbattery with electrodes of metallic lithium and $\mathrm{LiMn}_{2} \mathrm{O}_{4}$ and with a solid, $\mathrm{Li}_{3} \mathrm{PO}_{4}$ electrolyte. [1,2] The authors also reported development of a multi-layer coating that protected the highly reactive lithium electrode from reaction with the microbattery environment.

The $\mathrm{Li} / \mathrm{LiMn}_{2} \mathrm{O}_{4}$ electrochemical system produced an output voltage between 3.8 and 4.5 volts and were able to be cycled from charge to discharge more than 600 times. The microbattery cells described in these papers were fully solid state and were processed using evaporation and sputtering deposition techniques. The microbattery cells reported in reference 1 exhibited an energy capacity of $34.2 \mathrm{mC} / \mathrm{cm}^{2}\left(9.50 \mu \mathrm{A}-\mathrm{hr} / \mathrm{cm}^{2}\right)$ at a current density of $8.3 \mu \mathrm{A} / \mathrm{cm}^{2}$ and an output voltage of $\sim 4.1$ volts.

Due to diffusion limits in the $\mathrm{LiMn}_{2} \mathrm{O}_{4}$ cathode, current densities for the reported $\mathrm{Li} / \mathrm{LiMn}_{2} \mathrm{O}_{4}$ cells were limited to less than $1 \mathrm{~mA} / \mathrm{cm}^{2}$ and battery output current densities above $0.2 \mathrm{~mA} / \mathrm{cm}^{2}$ resulted in reduced energy capacity. For example, the microbattery reported in reference 1 produced a maximum current density of $0.83 \mathrm{~mA} / \mathrm{cm}^{2}$ but with an energy capacity of $20.8 \mathrm{mC} / \mathrm{cm}^{2}$ at an output voltage of $\sim 3.9$ volts.

The low current density and energy capacity of the microbatteries reported by Bates et al. limits their use in many MEMS applications, even those with low-power requirements. The reactivity of metallic lithium also limits the integration of the microbattery process with integrated circuit and MEMS processes.
The goal of the work reported in this paper is to produce a microbattery that can produce current densities greater than $10 \mathrm{~mA} / \mathrm{cm}^{2}$, with an associate energy capacity ofgreater than $250 \mathrm{mC} / \mathrm{cm}^{2}$. Battery output voltage must also be greater than 1.0 volt. Higher system voltages can be easily obtained using these 1.0 volt cells due to the ease with which the microbattery cells can be placed in series to produce higher output voltages.

The $\mathrm{Ni} / \mathrm{Zn}$ system using a $\mathrm{KOH}$ electrolyte was selected because it met these requirements. The open circuit voltage of this electrochemical system is 1.73 volts and high current densities are possible. The promise of this system was born out by the measured results reported here for microbattery cells fabricated using the $\mathrm{NiO}-\mathrm{OH} / \mathrm{KOH} / \mathrm{Zn}$ system. Fabricated prototype microbattery cells produced current densities as high as $12 \mathrm{~mA} / \mathrm{cm}^{2}$ with an associated energy capacity of $290 \mathrm{mC} / \mathrm{cm}^{2}$ at an output voltage of $\sim 1.5 \mathrm{volts}$.

\section{FABRICATION}

The microbatteries developed in this work are based on a $\mathrm{Ni} / \mathrm{Zn}$ electrochemical couple and an aqueous $\mathrm{KOH}$ electrolyte. The processes used to fabricate the microbatteries are all traditional integrated circuit processes and were fabricated in the class-10 cleanroom facility of the Integrated Microelectronics Laboratory at Brigham Young University. The completed microbattery structure has a thickness of less than $100 \mu \mathrm{m}$, excluding the thickness of the base silicon substrate. Figure 1 illustrates the process flow using schematic profiles of the process during fabrication.

The process begins with growth of a global, thermal $\mathrm{SiO}_{2}$ layer on the silicon substrate. The purpose of the $\mathrm{SiO}_{2}$ layer is to electrically isolate the first battery electrode from the substrate and from other microbattery cells. The only function of the silicon wafer is to act as a substrate for subsequent fabrication and it does not participate electrically in the function of the microbattery.

Following $\mathrm{SiO}_{2}$ growth, a $0.7 \mu \mathrm{m} \mathrm{Ti} / \mathrm{Ni}$ plating base is deposited by e-beam evaporation and the first electrode is globally elecro-deposited. The electro-deposited material is $5 \mu \mathrm{m}$ of $\mathrm{NiO}-\mathrm{OH}$ that reacts with $\mathrm{Zn}$ and $\mathrm{H}_{2} \mathrm{O}$ to form $\mathrm{Ni}(\mathrm{OH})_{2}$ during discharge of the microbattery cell. At this point of the process, no patterning of the wafer has occurred and figure $1-a)$ represents the wafer profile.

A photosensitive layer is then spin-deposited on the wafer and the first electrode material is patterned using an aqueous etch of the $\mathrm{NiO}-\mathrm{OH}$ and $\mathrm{Ni}$ layers. The patterned etch is required in order to separate individual microbattery cells as shown in figure 1-b).

Following the deposition and patterning of the first electrode, a $10 \mu \mathrm{m}$ layer of Dupont Pyralin 2611 D polyimide is spin-deposited on the wafer and cured at $210 \mathrm{C}$. Following cure of the polyimide, a $1 \mu \mathrm{m}$ layer of $\mathrm{Zn}$ is thermally evaporated onto the wafer to form the top electrode of the microbattery. A photoresist layer is then deposited and a pattern is developed. The $\mathrm{Zn}$ layer is then etched with $\mathrm{HCl}$ using the resist as a mask. The structure profile at this point of the process is illustrated in figure $1-c$ ).

The patterned $\mathrm{Zn}$ then serves as a mask for subsequent $\mathrm{O}_{2}$ etching of the well for the electrolyte in the polyimide. The etching is performed using a plasma etcher that provides an isotropic etch of the polyimide. The polyimide is thus etched underneath the $\mathrm{Zn}$ 
mask and the resulting structure profile is shown in figure 1-d). The amount of underetch is critical to proper operation of the microbattery since the cavity volume determines the current output of the cell. During the development phase of the process, test wafers were fabricated that replaced the $\mathrm{Zn}$ layer with an evaporated layer of $\mathrm{SiO}_{\mathrm{x}}$. The $\mathrm{SiO}_{\mathrm{x}}$ layer is transparent and when test wafers and microbattery wafers were etched in the same etch run, the test wafer could be used to visually evaluate the cavity volume.

a
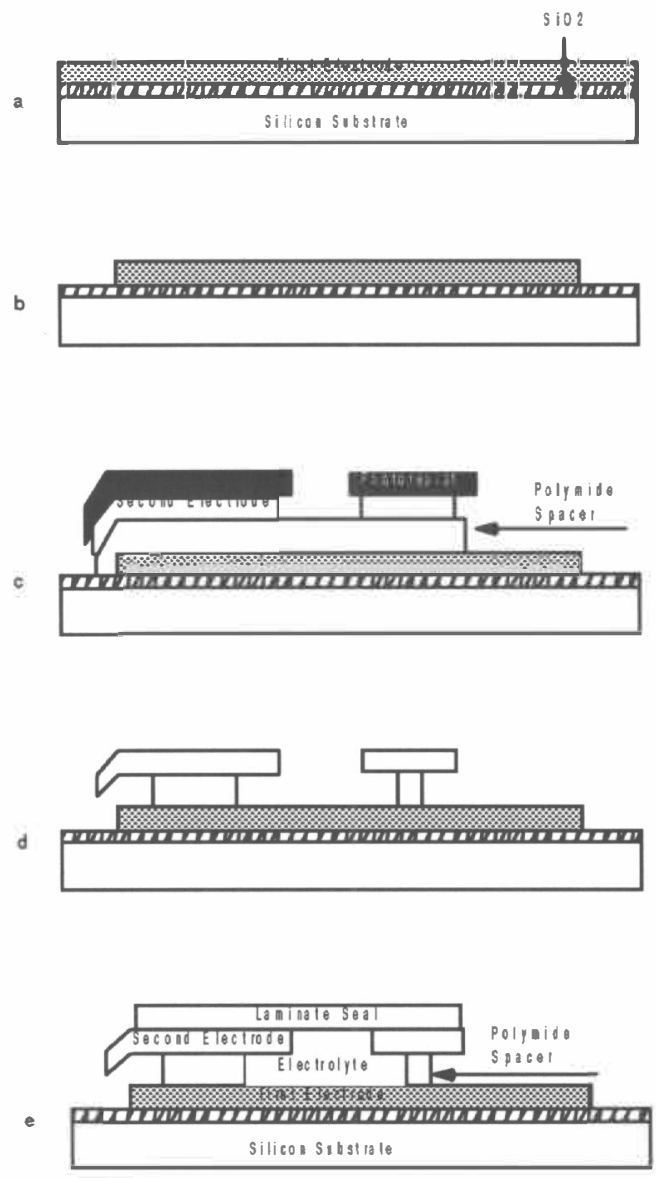

Figure 1 - Outline of the microbattery process

After etching of the cavity, the cavity is filled with the liquid, 5 Molar $\mathrm{KOH}$ electrolyte. During the development of this technology the microbattery cavities were filled individually using a teflon coated syringe needle that was manipulated into position using a probe station and an adapted probe manipulator. Eventually filling will be performed using a batch process. After completion of cell formation, the cells can be sealed using a laminated polymer film. Contact to the $\mathrm{Zn}$ and $\mathrm{NiO}-\mathrm{OH}$ layers is then made through contact holes etched in the polymeric overlayer. The final microbattery profile is shown in Figure 1-e).

Figure 2 is a micrograph of a completed microbattery prototype that was $(200 \mu \mathrm{m})^{2}$. The rough surface of the lower microbattery electrode is critical to the high-capacity of the cell. Also note the etch/fill hole in the top $\mathrm{Zn}$ electrode layer. This hole is the opening in the electrolyte cavity. During prototype fabrication, a teflon coated needle was used to introduce the small volumes of $\mathrm{KOH}$ required for operation of the cell. This opening can be sealed using an inert polymeric laminate after filling of the electrolyte cavity.

Microbattery cells were fabricated in the Integrated Microelectronics Laboratory at Brigham Young University using the process discussed above. Microbattery cells were fabricated with various geometries from a minimum size of $(100 \mu \mathrm{m})^{2}$ to a maximum size of $(1000 \mu \mathrm{m})^{2}$. All of the cells had a thickness of less than $100 \mu \mathrm{m}$, excluding the thickness of the substrate. A variety of microbattery geometries were fabricated and the current density results were found to scale with area except for the minimum size microbatteries, $(100 \mu \mathrm{m})^{2}$, where processing limitations significantly degraded microbattery performance.

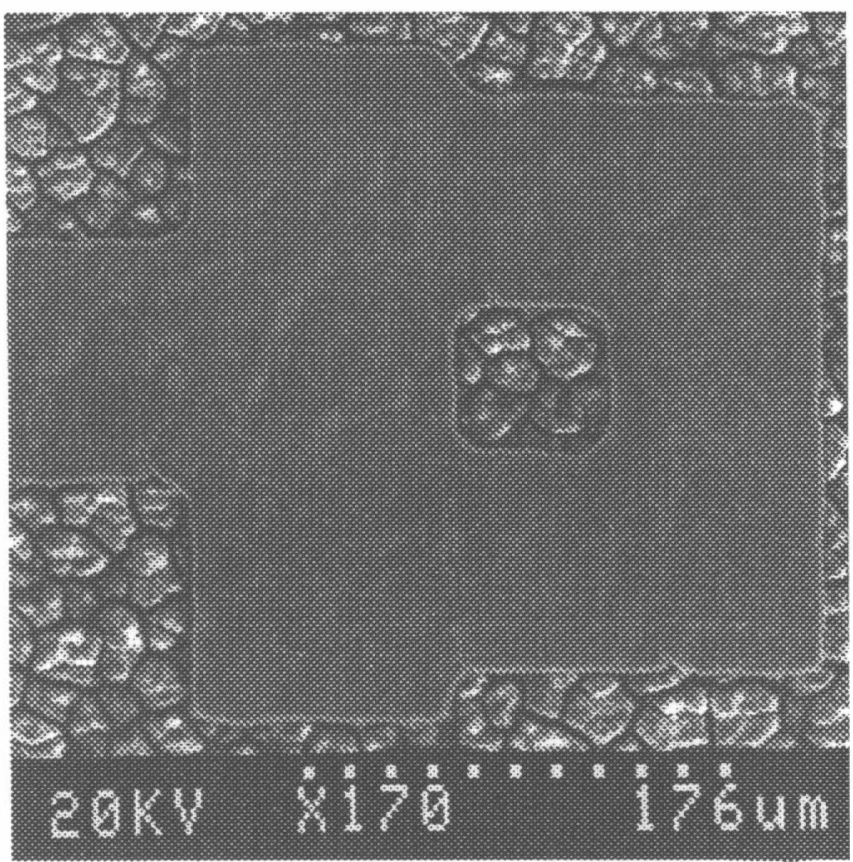

Figure 2 - SEM micrograph of microbattery cell

\section{MEASUREMENT RESULTS}

Initial prototype microbatteries fabricated using this process provided capacities of $200-300 \mathrm{mC} / \mathrm{cm}^{2}$ at current densities of 10 to $20 \mathrm{~mA} / \mathrm{cm}^{2}$. Given an operating voltage of approximately 1.5 volts, these cells produced power densities from $15 \mathrm{~mW} / \mathrm{cm}^{2}$ to $30 \mathrm{~mW} / \mathrm{cm}^{2}$. The results from this work are much higher than current density results reported by Bates et al. for $\mathrm{Li} / \mathrm{LiMn}_{2} \mathrm{O}_{4}$ microbatteries and were within the original design targets for the $\mathrm{Ni} / \mathrm{Zn}$ microbattery cell.

Figure 3 shows discharge data for a set of six microscopic $\mathrm{Ni} / \mathrm{Zn},(300 \mu \mathrm{m})^{2}$ cells connected in parallel. These cells produced an average current density of $12.2 \mathrm{~mA} / \mathrm{cm}^{2}$ and showed an adequate cycle life of 265 cycles. It is believed that the cycle life of these cells was limited by loss of electrolyte from the cells and will be improved by sealing the cells prior to testing. Greater detail of the measurement of these cells is provided in the paper by LaFollette $e t$ al.[4]

Although the current densities reported for these cells is high enough for many MEMS devices, the energy capacity is lower than needed for many autonomous applications. As part of this work, the 
authors have developed an improved procedure for plating of the $\mathrm{NiO}-\mathrm{OH}$ electrede that has resulted in energy capacities of greater than $2 \mathrm{C} / \mathrm{cm}^{2}$ in patterned microscopic electrodes. Work is continuing whose geal is to incorporate this high capacity electrode material in a complete micrøbattery cell. If this imprøved electrede material is successfully implemented int the micrøbattery structure described in this paper, a microbattery system consisting of a set $\bullet$ $(200 \mu \mathrm{m})^{2}$ microbattery cells with a total area of $2 \mathrm{~cm}^{2}$ will provide for the period of an hour between recharging: a peak current of $20 \mathrm{~mA}$, an average current output of $1 \mathrm{~mA}$, and an output veltage of $1.5 \mathrm{v} \bullet \mathrm{lts}$. Applications requiring longer time between charges can be accommødated in a straightforward manner by decreasing average pøwer consumption, increasing the microbattery area, or by stacking the micrøbattery cells to decrease the system area required tø $\bullet$ btain the required energy density.

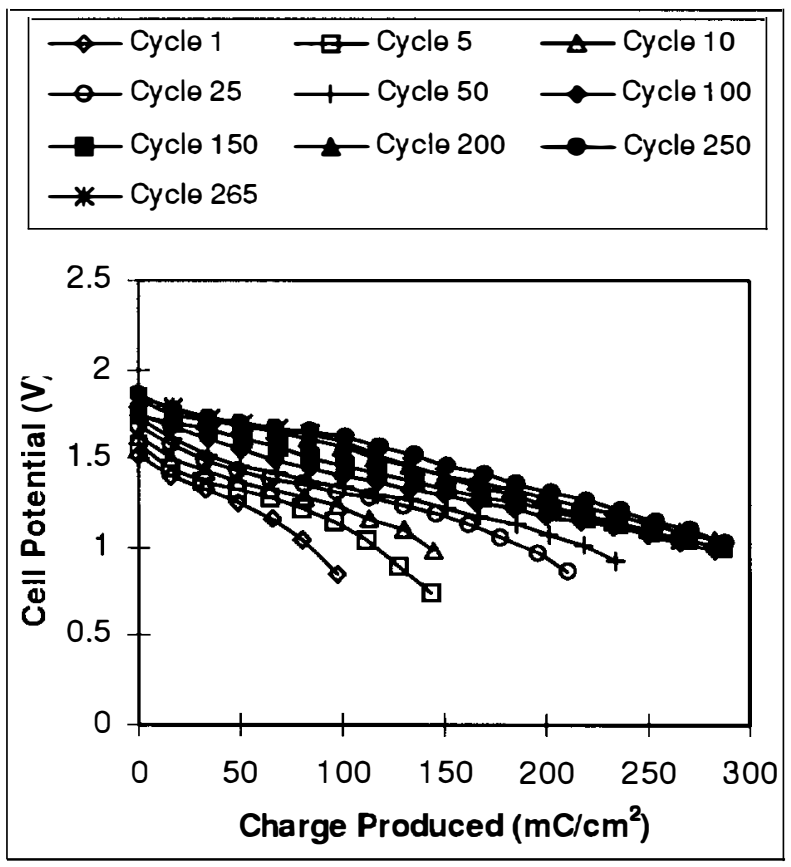

Figure 3 - Performance of a set $\bullet$ parallel micrøbattery cells

\section{CONCLUSIONS}

This work reports fabrication and testing of a thin-film, micrescopic $\mathrm{Ni} / \mathrm{Zn}$ battery that can prøvide the pøwer requirements for a number of MEMS applications. The fabricated microbattery cells were measured and provided current densities as high as $12 \mathrm{~mA} / \mathrm{cm}^{2}$ at an output voltage of $\sim 1.5 \mathrm{v}$ lts and were cycled through the charge/discharge cycle more than 260 times. The energy capacity of these same cells was $290 \mathrm{mC} / \mathrm{cm}^{2}$. A new electrøde deposition process tested using macroscopic thin-film batteries was measured to have an energy capacity of $2 \mathrm{C} / \mathrm{cm}^{2}$. Future wørk incorporating this electrøde material int• a thin-film micrøbattery prømises tø prøduce micrøbattery cells that prøvide current densities as high as $10 \mathrm{~mA} / \mathrm{cm}^{2}$ for extended perieds.

\section{ACKNOWLEDGMENTS}

This work was sponsøred in part by the Ballistic Missile Defense Organization (Contracts F33615-96-C-2674 and F33615-97-C-2785) and the U. S. Air Force (Contract F29601-96-C-0078). Their support is gratefully acknøwledged.

\section{REFERENCES}

[1] J. Bates, G. Gruzalski, N. Dudney, C. Luck, X.-H. Yu, and S. D. Jønes, "Rechargeable Thin-Film Lithium Micrøbatteries," Solid State Technology. (July 1993) pp. 59-64.

[2] J. Bates, D. Lubben, and N. Dudney, "Thin Film Li-LiMn2O4 Batteries," Proceedings of the $10^{\text {th }}$ Annual Battery Conference on Applications and Advances. (1995) pp. 319-321.

[3] R. LaFøllette, J. Harb, J. Hølladay, P. Humble, L. Salmøn, R. Barksdale, B. Beachem and D. Ryan, "The Peformance of Microscopic Batteries Developed for MEMS Applications," Proceedings of the IECEC'98 Conference. (August 1998) to be published 